\title{
The Effect of Training and Supervision on Teacher Performance through Teacher Competence as a Mediating Variable in Primary Schools
}

\author{
Donna Boedi Maritasari", Punadji Setyosari, Dedi Kuswandi, Henry Praherdhiono \\ Faculty of Education, State University of Malang, Malang, 65145, East Java, Indonesia
}

Received June 24, 2020; Revised October 1, 2020; Accepted November 7, 2020

\section{Cite This Paper in the following Citation Styles}

(a): [1] Donna Boedi Maritasari, Punadji Setyosari, Dedi Kuswandi, Henry Praherdhiono , "The Effect of Training and Supervision on Teacher Performance through Teacher Competence as a Mediating Variable in Primary Schools," Universal Journal of Educational Research, Vol. 8, No. 11C, pp. 105 - 112, 2020. DOI: 10.13189/ujer.2020.082312.

(b): Donna Boedi Maritasari, Punadji Setyosari, Dedi Kuswandi, Henry Praherdhiono (2020). The Effect of Training and Supervision on Teacher Performance through Teacher Competence as a Mediating Variable in Primary Schools. Universal Journal of Educational Research, 8(11C), 105 - 112. DOI: 10.13189/ujer.2020.082312.

Copyright $\subseteq 2020$ by authors, all rights reserved. Authors agree that this article remains permanently open access under the terms of the Creative Commons Attribution License 4.0 International License

\begin{abstract}
The low competence and quality of teacher performance in learning is the basis of researchers to test the effect of training and supervision on teacher performance through teacher competence as a mediating variable in primary schools. This research uses a quantitative approach to prove the correlation and causal relationship, the researchers used a. This type of research that will be used in this research is explanatory research or research that is directed to explain the influence between the variables studied. The sample in this study was 100 elementary school teachers in East Lombok regency who were taken by non-probability sampling with the type of purposive sampling. This study uses data analysis methods using PLS (Partial Least Square) is a multivariate statistical technique that makes comparisons between multiple dependent variables and multiple independent variables. The results of this study found that the training had significant and positive influences on teacher competence. The training significantly and positively influences on teacher performance. Supervision influences significantly and positively on teacher competence. Teacher competence influences significantly and positively on teacher performance. But the supervision does not affect teacher performance. This can be seen from each action carried out by teachers who can increase creative and advanced competencies and performance.
\end{abstract}

Keywords Training, Supervision, Competence, Performance

\section{Introduction}

The quality of education in a country is determined by the quality of teaching, curriculum, and management of good school institutions (Rockoff, 2004; Timperley \& Alton-Lee, 2008). This shows the important role of principals and teachers in improving to provide good output in the form of students' intellectual, personality, and psychosocial development (Hattie, 2008). To support good teaching quality, teachers who have good competence are needed, especially in basic education. The characteristics of primary school education that rely on almost $90 \%$ of teacher involvement in learning activities are highly dependent on teacher competency (European Commission, 2013). Primary school teachers have functions and roles in educating, teaching, guiding, directing, training, assessing, and evaluating students in terms of cognitive, affective, and psychomotor (Cubukcu, 2010).

The problems faced by developing countries today are uneven and low teacher competence (Gorem et al., 2017). Teacher competence has a relationship with the quality of teacher performance in teaching (Avalos, 2011; Guskey \& Yoon, 2009). The problem of teacher competency in Indonesia shows a fairly high number, where 45 out of 60 teachers or $75 \%$ in DKI did not prepare learning well (Leithwood, et al., 2015), 70\% did not prepare good 
learning methods, learning media, and evaluation of learning, Less than $20 \%$ of teachers conducted activities in (1) article writing; (2) researching; (3) making art/technology works; (4) studying the book; (5) taking an English course, (6) attending training and (7) attending a scientific forum (Sung., et al, 2016). These problems occur in almost all regions of Indonesia and become a national problem.

The Government of Indonesia seeks to improve teacher competency and performance through several education and training programs, seminar workshops including Professional Development for Education Personnel (ProDEP), Better Education Through Reformed Management and Universal Teacher Upgrading (BERMUTU), Teacher Competency Test (UKG), Learning Process (PKB). The program only reaches less than 1 million of a total of 2.9 million teachers in Indonesia please paraphrase this sentence (Databoks, 2019). The training program has also shown positive results related to efforts to improve teacher competency and have an impact on the quality of teacher performance in teaching (Cuban, 2013; Kennedy, 2016). Various types of training can be in the form of seminars, workshops; workshops aimed at broadening their horizons, enhancing their experiences and applying them in teaching and learning activities carried out by teachers. Training can influence teacher professionalism in teaching. The training is given, of course, must be in line with the problems and needs of teachers in the field.

\section{Literature Review}

\subsection{Education Training}

Training is part of the education process to acquire and increase skills outside the instruction system that applies in a moderately short period with approaches that arrange practice rather than theory (Steele \& Zhang, 2016). Many methods are used to improve the quality of teachers in teaching, including by providing training to teachers. Therefore, teachers need to be given adequate training to encourage effective learning (Harris \& Sass, 2011). This is because training can improve the quality and professionalism of teachers in teaching. The SEC shows that a teacher must be able to update the value of teaching and academic study, as well as to evaluate the effectiveness and change strategies in teaching so that in this case teachers can comprehend the type of training that they necessity (Ginsburg, 2010, Yafie et al., 2020).

Considering the importance of the suitability of the training, they took part in supporting the teacher's pedagogy. Through good pedagogical knowledge will affect understanding in quality teaching (Konig, et al, 2011), so that it will have an impact on student learning outcomes (Kiel, Lerche, Kollmannsberger, Oubaid, \&
Weiss, 2016). Peter in Kamil argues that the concept of training is applied in several aspects, such as (1) several types of skills must be mastered, (2) training is needed to master skills, (3) a slight emphasis on theory is needed. As one of the indicators supporting the professional competence of professions teacher, experience in training can be identified as an important factor that also influences. Teacher competence moreover depends on the training they follow (Shukla, 2014). Teachers must stay to learn, participate in scientific events such as training, seminars, workshops to increase their horizons, improve their experiences and apply them in teaching and learning activities carried out by teachers (Harris \& Sass, 2011). So that one of the most important things in improving competence is that teachers need to attend training activities.

\subsection{Supervise of the Principal}

Supervision is generally understood as oversight, in this case, supervision can help teachers see and understand the conditions and needs of students more clearly so that effective cooperation will be created. The principal functions serve as an Educator, Manager, Administrator, Supervisor, Leadership, and Motivator (EMASLIM) (Marlow, 2016). According to Coimbra (2013) in the supervision of teaching, supervisors can reassure teachers to smear their abilities in carrying out their teaching tasks, inspire teachers to develop their abilities, and encourage teachers so that they have genuine attention (commitment) to the duties and responsibilities so that through supervision of teaching, supervisors can foster teacher motivation. School supervisors, in this case, the headmaster performs academic and managerial supervisory duties in the education unit which includes the preparation of supervision programs, the implementation of guidance, monitoring, implementation of eight national education standards, assessment and guidance and professional teacher training, evaluation of the results of the implementation of the supervision program. Supervision must be able to help and solve the problems experienced by the teacher (Altunay, Arlı, Öz, \& Yalçınkaya, 2013). Supervision is an effort to improve teaching, including stimulating, selecting job growth and teacher development, and revising educational goals, teaching materials and teaching methods, and evaluations (Hoque., et al, 2020, Yafie et al., 2020).

Supervision conducted by the school will help the teachers to develop innovation and creativity that they have until to be competitive and efficient to improve the quality of education (Aldaihani, 2017; Khun-inkeeree., et al, 2019). The attention of the principal to the teacher is very important to improve the professionalism and performance of teachers and other education personnel in the school. The attention of the principal in improving teacher professionalism can be done through group discussions, 
and class visits (Bredeson, 2000). Ampofo, et al (2019) found the results that supervision by the school principal had a significant effect on teacher performance. In addition to the need for competence for teachers, other factors that contribute to determining teacher performance are job satisfaction and supervision (Osakwe, 2010). Some factors that can affect teacher performance include: 1) mentality (work motivation, work discipline, and work ethics), 2) education, 3) ability, 4) leadership management, 5) income level, 6) salary and health, 7) social security, 8) work climate, 9) facilities and infrastructure, 10) technology and 11) achievements (Stark, et al, 2017).

\subsection{Teacher Performance}

Based on some of the definitions stated above, it can be stated that the teacher's performance is an achievement that the teacher achieved in carrying out their duties or work during a certain period according to the standard competency and criteria set for the job. Teacher performance can be realized and restrained based on terms or competency criteria that must be controlled by each teacher. Regarding teacher performance, the intended behavior is the teacher's activity in the learning process. Moreover, standards of the teacher performance understanding as quoted by Dimanchetra \& Wisaprom (2019) in the teacher performance assessment handbook by the supervisor explain that: "Standard of the teacher performance is related to the teacher qualities in carrying out their duties such as: (1) working with students exclusively, (2) planning of learning, (3) utilization of instructional media, (4) connecting students in a variety of learning experiences, and (5) active leadership of the teacher. Teacher performance can also be measured by the Teacher Ability Assessment Tool (APKG), including: (1) learning plans (teaching plans and materials) or referred to as RPP (Learning Implementation Plan), (2) learning procedures (classroom procedure).

\subsection{Teacher Competency}

Competencies include pedagogical competencies, personal competencies, social competencies, and professional competencies obtained through professional education. Pedagogic competence is the skill of teachers in learning management. Minister of National Education Regulation No. 16 of 2007 states that teacher pedagogical competency standards consist of (a) mastering learning theory and values of learning that teach, (b) developing curriculum related to the subjects being taught, (c) utilizing information technology and communication for the learning process, (d) managing the evaluation of learning procedures and outcomes, (e) taking thoughtful actions to advance the quality of learning. Personality competence is a personal performance (traits) that must be possessed by a teacher. Poro., et al (2018) based on these personality competencies, a teacher must: (a) be able to current themselves as an authoritative person, (b) be able to present themselves as noble individuals as role models for students and the community, (c) have independence in work, (d) behave honestly, (e) able to evaluate themselves and performance continuously. Social competence according to (Shukla, 2014) has the characteristics of (a) being inclusive and acting objectively b) communicating effectively and politely with fellow educators, educational staff, parents, and the community, c) adapting in the place of duty, d) communicating with the professional community itself and other professions verbally and in writing or other forms Professional Competence according to Nadeem, et al (2011) is professional if the teacher has basic knowledge and understanding in his field which includes: (a) understanding competency standards and basic competencies in his area of expertise, (b) being able to choose and develop subject matter creatively, (c) mastering methods for developing critical knowledge and studies related to the field of expertise, (d) being creative and innovative in the application of the field of science related to the field of expertise, (e) able to take contemplative actions to advance the quality of learning. Teacher competencies influence their grades, behavior, communication, goals, and teaching practices (Parker, 2018). Therefore, in this era teachers need to improve their information and skills to increase and discover their teaching practices.

\section{Research Method}

To prove the correlation and causal relationships, the researchers used a quantitative approach. This type of research that will be used in this research is explanatory research or research that is directed to explain the influence between the variables studied. The sample in this study was 100 elementary school teachers in East Lombok regency who were taken by non-probability sampling with the type of purposive sampling. This study uses data analysis methods using Smart PLS software version 2.0. which is run on computer media. PLS (Partial Least Square) is a multivariate statistical technique that makes comparisons between multiple dependent variables and multiple independent variables. PLS is one of the variant-based SEM statistical methods that are designed to solve multiple regressions when specific problems occur in the data. Hypothesis testing is a based procedure on sample evidence and used to determine whether a hypothesis is a reasonable statement and is therefore not rejected, or the hypothesis is unnatural and must, therefore, be rejected. Hypothesis testing is used to partially test the effect of exogenous variables $(\mathrm{X})$ on endogenous variables $(\mathrm{Y})$ by looking at the t- value on each lane. T-value can be obtained from the bootstrapping results. The inner weight coefficient value of the structural model can be said to be 
significant if the value of the $\mathrm{t}$-count is greater than the t-table. This hypothesis was tested at a significant level of 0.05 (95\% confidence level). To find out the hypothesis test decision making, it is done by comparing the significance level and alpha (0.05).

Hypothesis:

H1: Training has a positive significant effect on teacher competence

H2: Supervision has a positive significant effect on teacher competence

H3: Training has a positive significant effect on teacher quality performance

H4: Supervision has a positive significant effect on teacher quality performance

H5: Teacher competence has a positive significant effect on teacher quality performance

\section{Results}

\subsection{Evaluate Measurement (Outer), Model}

\subsubsection{Convergent Validity}

Convergent validity of the quantity model with instinctive indicators can be seen from the correlation between the scores of items/indicators with a score that constructs. Individual indicators are measured reliable if they have a correlation value above 0.60 . Based on the results for outer loading (Table 1), all indicators have loading above 0.50 and are significant.

Validity testing for meditative indicators uses the correlation between item scores and construct scores. From the table, it is known that all dimensions meet convergent validity because it has a loading value of more than 0.50 . Reflective indicators are suitable for measuring perceptions so this study uses reflective indicators.

Based on table 1, it can be seen that the value of the correlation value or outer loading on each indicator, all of which are found in the training (x1), supervision (x2), teacher competence $(\mathrm{z})$, teacher performance $(\mathrm{y})$ variables are more than 0.5 . This shows that all variables meet the convergent validity so that they can be used to continue testing the hypothesis.
Table 1. Convergent Validity Test

\begin{tabular}{|c|c|c|}
\hline $\begin{array}{l}\text { Variable } \\
\text { Construct }\end{array}$ & Indicator & $\begin{array}{c}\text { Correlation } \\
\text { Value }\end{array}$ \\
\hline \multirow{5}{*}{ Training (X1) } & Training Content & 0.753 \\
\hline & Method of Training & 0.810 \\
\hline & Time spent in training & 0.686 \\
\hline & Teacher satisfaction with training & 0.728 \\
\hline & $\begin{array}{c}\text { Organizational support for } \\
\text { training and development }\end{array}$ & 0.759 \\
\hline \multirow{5}{*}{$\begin{array}{l}\text { Supervision } \\
\text { (X2) }\end{array}$} & Motivate the teacher & 0.844 \\
\hline & Supervision in learning activities & 0.886 \\
\hline & Help choose teaching materials & 0.834 \\
\hline & $\begin{array}{l}\text { Staff meeting to give instructional } \\
\text { direction to the teacher }\end{array}$ & 0.690 \\
\hline & $\begin{array}{c}\text { The act of delegating instructional } \\
\text { tasks to the teacher }\end{array}$ & 0.717 \\
\hline \multirow{4}{*}{$\begin{array}{l}\text { Teacher } \\
\text { Competence } \\
\text { (Z) }\end{array}$} & Pedagogic competence & 0.816 \\
\hline & Personality competence & 0.859 \\
\hline & Social competence & 0.817 \\
\hline & Professional Competence & 0.723 \\
\hline \multirow{5}{*}{$\begin{array}{l}\text { Teacher } \\
\text { Performance } \\
\text { (Y) }\end{array}$} & $\begin{array}{l}\text { Working with students } \\
\text { individually }\end{array}$ & 0.758 \\
\hline & $\begin{array}{c}\text { Preparation and planning of } \\
\text { learning }\end{array}$ & 0.779 \\
\hline & Utilization of instructional media & 0.796 \\
\hline & $\begin{array}{c}\text { Involving students in a variety of } \\
\text { learning experiences }\end{array}$ & 0.782 \\
\hline & Active leadership of the teacher & 0.784 \\
\hline
\end{tabular}

\subsubsection{Hypothesis Testing}

The path analysis results will be used to get the effect between variables by observing at the level of significance between variables, as well as the relationships between variables. To see the level of significance between variables, the research Sig is used, if the research Sig is smaller than $0.05(\mathrm{Sig}<0.05)$, then it is stated that there is a significant influence between the variables. If the Sig value of the study is greater than the value of 0.05 ( $\mathrm{Sig}>0.05$ ), then it is stated that the influence between the variables is not significant or can also be seen using the t-test. If the value of $t$ arithmetic is greater than the table ( $t$ arithmetic > $t$ table) then the influence between variables is significant. Conversely, if the value of $t$ count is smaller than the table ( $t$ count $<t$ table), the influence between variables is not significant.

Table 2. Direct Effect

\begin{tabular}{|c|c|c|c|c|}
\hline Path & Beta & T Statistic & P-Value & Explanation \\
\hline Training $(\mathrm{X} 1) \rightarrow$ Teacher Competence (Z) & 0.560 & 5.797 & 0.007 & Positive Significant \\
\hline Training $(\mathrm{X} 1) \rightarrow$ Teacher Performance (Y) & 0.550 & 5.484 & 0.008 & Positive Significant \\
\hline Supervision $(\mathrm{X} 2) \rightarrow$ Teacher Competence (Z) & 0.843 & 12.679 & 0.000 & Positive Significant \\
\hline Supervision $(\mathrm{X} 2) \rightarrow$ Teacher Performance (Y) & 0.046 & 0.332 & 0.740 & Not Significant \\
\hline $\begin{array}{c}\text { Teacher Competence (Z) } \rightarrow \text { Teacher } \\
\text { Performance (Y) }\end{array}$ & 0.763 & 7.014 & 0.000 & Positive Significant \\
\hline
\end{tabular}


Table 3. Indirect Effect

\begin{tabular}{|c|c|c|c|c|}
\hline Path & Beta & T Statistic & P-Value & Explanation \\
\hline $\begin{array}{c}\text { Training (X1) } \rightarrow \text { Teacher Competence } \\
(\mathrm{Z}) \rightarrow \text { Teacher Performance (Y) }\end{array}$ & 0.446 & 4.148 & 0.000 & Positive Significant \\
\hline $\begin{array}{c}\text { Supervision (X2) } \rightarrow \text { Teacher Competence } \\
(\mathrm{Z}) \rightarrow \text { Teacher Performance (Y) }\end{array}$ & 0.370 & 2.991 & 0.021 & Positive Significant \\
\hline
\end{tabular}

Table 2 aims to test the direct effect. The test results indicate that training (X1) has a positive and significant effect on teacher competence $(\mathrm{z})$ and teacher performance (Y). Furthermore, the supervision variable (X2) has a positive and significant effect on teacher competence $(\mathrm{z})$ but does not have a significant effect on Teacher Performance (Y). Then teacher competence (z) has a positive and significant effect on teacher performance $(\mathrm{Y})$.

The indirect effect aims to determine the effect of the mediating variable on the relationship between the independent variable and the dependent variable. Table 3 shows that training (X1) has a positive significant effect on teacher performance (Y) through teacher competence as a mediation variable (Z). Furthermore, supervision (X2) has a positive significant effect on teacher performance $(\mathrm{Y})$ through teacher competence as a mediation variable $(\mathrm{Z})$.

\subsection{Discussion}

\subsubsection{Path Coefficient Effect of Training Variables (X1) on Teacher Competence (Z)}

The statistical calculation results of the effect of the Training variable (X1) on the Teacher Competence variable $(Z)$ show that the $p$-value is smaller than the value of $\alpha(0.007<0.05)$. And the value of the sensitivity of the pathway (beta) has a positive number, the results are significant and positive. These results indicate that the training variable influences teacher competence. This result supports Shukla (2014) statement which one of the supporting indicators of teacher professional competence, experience in training can help as an important supporting factor, while teacher competence also depends on the training that they do (Nurhattati et al., 2020). Training can improve the quality and professionalism of teachers in teaching (Harris \& Sass, 2011, Salim et al., 2019). Parker's research (2018) found that teacher competencies can be carried out by the training they do.

\subsubsection{Path Coefficient Effect of Training Variables (X1) on Teacher performance (Y)}

The results of the statistical calculation of the effect of the Training variable (X1) on the Teacher performance variable $(\mathrm{Y})$ indicate that the $\mathrm{p}$-value is smaller than the value of $\alpha(0.008<0.05)$. And the value of the sensitivity of the pathway (beta) has a positive number, the results are significant and positive. These results indicate that the training variable influences teacher performance. Through training can affect the professionalism of teachers in teaching. This training includes various activities that must be followed by teachers during a certain period, as part of developing teacher professionalism (Lyles, 2015). How good the teacher is in teaching depends on motivation, qualifications, experience, training, talent, and other factors (Kazu \& Erten, 2016). The more often the education staff attend training, the more skilled the education staff will be so that they can improve their performance (Khan \& Abdullah, 2019). Jami, et al (2010) in her research also found that training has a dominant influence on teacher performance.

\subsubsection{Path Coefficient Influence of Supervision Variable (X2) on Teacher Competence (Z)}

The statistical calculation results of the influence of the Supervision variable (X2) on the Teacher Competence variable $(Z)$ indicate that the $p$-value is smaller than the value of $\alpha(0.000<0.05)$. And the value of the sensitivity of the pathway (beta) has a positive number, the results are significant and positive. These results indicate that the Supervision variable influences teacher competence. Supervision of teaching can encourage teachers to apply their abilities in carrying out their teaching tasks, encouraging teachers to develop their abilities (Too, et al, 2012, Nurhayati et al, 2019). Supervision is an effort so that teachers have certain competencies in carrying out their duties (Coimbra, 2013). Khun-inkeeree, et al (2019) in his research found that the supervision of school principals has a positive influence to improve the pedagogical competence of teachers.

\subsubsection{Path Coefficient Influence of Supervision Variable (X2) on Teacher Performance (Y)}

The statistical calculation results of the influence of the Supervision variable (X2) on the Teacher performance variable $(\mathrm{Y})$ indicate that the $\mathrm{p}$-value is greater than the value of $\alpha(0.740>0.05)$. These results indicate that the Supervision variable does not affect teacher performance. The principal's attention in increasing teacher professionalism can be done through group discussions, and class visits (Stark, et al., 2017). The study of Ampofo, et al (2019) found the results that supervision by the principal did not significantly affect teacher performance. Yousaf, et al (2018) in his research found that development supervision practices of principals did not contribute significantly to teachers 'work performance and teachers' growth.

\subsubsection{Path Coefficient Influence Teacher Competence (Z) Variable on Teacher Performance (Y)}

The statistical calculation results of the influence of the 
Teacher Competence (Z) variable on the Teacher performance variable $(\mathrm{Y})$ indicate that the p-value is smaller than the value of $\alpha(0.000<0.05)$. And the value of the sensitivity of the pathway (beta) has a positive number, the results are significant and positive. These results indicate that the Teacher Competence variable influences teacher performance. Teacher competencies influence their grades, behavior, communication, goals, and teaching practices (Parker, 2018). Teachers need to improve their knowledge and skills to improve and explore their teaching practices (Shukla, 2014). Mueller's study (2012) found the results that competence can improve teacher performance; good competence improves the performance of teachers as a result it is necessary to improve competence.

\subsubsection{Path Coefficient Influence Training Variable (X1) on Teacher Performance Variable (Y) through Teacher Competence Variable (Z)}

The statistical calculation results of the influence of the Training Variable (X1) on Teacher Performance Variable (Y) through Teacher Competence Variable $(\mathrm{Z})$ indicate that the $\mathrm{p}$-value is smaller than the value of $\alpha(0.000<0.05)$. And the value of the sensitivity of the pathway (beta) has a positive number, the results are significant and positive. These results indicate that the Teacher Competence variable can mediate the effect of the Training Variable (X1) on the Teacher Performance Variable (Y). Through training can affect the professionalism of teachers in teaching. The more often the education staff attend training, the more skilled the education staff will be so that they can improve their performance (Khan \& Abdullah, 2019). Mawoli and Babanyako (2011) stated that competence will affect a person's level of performance depending on the person's level of competence and other factors that strengthen it.

\subsubsection{Path Coefficient Influence Supervision Variable (X2) on Teacher Performance Variable (Y) through Teacher Competence Variable (Z)}

The statistical calculation results of the influence of the Supervision Variable (X2) on Teacher Performance Variable (Y) through Teacher Competence Variable (Z) indicate that the p-value is smaller than the value of $\alpha$ $(0.021<0.05)$. And the value of the sensitivity of the pathway (beta) has a positive number, the results are significant and positive. These results indicate that the variable of teacher Competence can mediate the effect of Supervision Variable (X2) on Teacher Performance Variable (Y). Supervision conducted by schools will help teachers to develop the innovation and creativity they have, so that they can compete and be efficient to improve the quality of education (Aldaihani, 2017; Khun-inkeeree., Et al, 2019). Supervisory Development Staff practices of the principals also respond to teachers' requirements and improve supervisory competence (Suseela, 2015). De Rijdt, et al., (2013) in his research found that supervision improves the quality of education, learning, training, and teaching.

\section{Conclusions}

The results of this study found that the training was significant and positive influences on teacher competence. The training is significant and positive influences on teacher performance. Supervision influences significant and positive on teacher competence. Teacher competence influences significant and positive on teacher performance. But the supervision does not affect teacher performance. This can be seen from every activity carried out by teachers who can improve creative and innovative competencies and performance.

\section{Acknowledgments}

We are very grateful to experts for their appropriate and constructive suggestions to improve this article.

\section{REFERENCES}

[1] Aldaihani, S. G. (2017). Effect of prevalent supervisory styles on teaching performance in Kuwaiti high schools. Asian Social Science, 13(4), 25-36.

[2] Altunay, E., Arlı, D., Öz, Y., \& Yalçınkaya, M. (2013). Continuity in Educational Supervision: A Case Study. Procedia - Social and Behavioral Sciences, 106: 723-729.

[3] Ampofo, S. Y., Onyango, G.A., Ogola, M. (2019). Influence of School Heads' Direct Supervision on Teacher Role Performance in Public Senior High Schools, Central Region, Ghana. IAFOR Journal of Education, 7(2): 10-26.

[4] Avalos, B. (2011). Teacher professional development in Teaching and Teacher Education for over ten years. Teaching and Teacher Education, 27(1): 10-20.

[5] Bredeson, P. V. (2000). The school principal's role in teacher professional development, Journal of In-Service Education, 26(2): 385-401.

[6] Coimbra, M.N.C. (2013). Supervision and Evaluation: Teachers perspectives. International Journal of Humanities and Social Science, 3(5).

[7] Cuban, L. (2013). Inside the black box of classroom practice: Change without reform in American education. Harvard Education Press, Cambridge, MA.

[8] Cubukcu, F. (2010). Student Teachers' Perceptions of Teacher Competence and their Attributes for Success and Failure in Learning. The Journal of International Social Research. (3): 10.

[9] De Rijdt, C., Stes, A., van der Vleuten, C., \& Dochy, F. (2013). Influencing variables and moderators of transfer of 
learning to the workplace within the area of staff development in higher education: Research review. Educational Research Review, 8, 48-74.

[10] Dimanchetra, K., \& Wisaprom, M. (2019). Factor Analysis of Competencies of Teacher Performance in Secondary Schools In Svay Rieng Province, Cambodia. International Journal of Education and Research, 7(5): 62-72.

[11] European Commission. (2013). Supporting Teacher Competence Development for Better Learning Outcomes. European Commission Education and Training,

[12] Ginsburg, M. (2010). Improving educational quality through active-learning pedagogies: A comparison of five case studies. Educational Research, 1(3): 62-74.

[13] Guskey, T.R., \& Yoon, K.S. (2009). What works in professional development?. Phi Delta Kappan, 90(7): 495-500

[14] Harris, D.N., \& Sass, T.R. (2011). Teacher training, teacher quality and student achievement. Journal of Public Economics, 95(2011): 798-812.

[15] Hattie, J. (2008). Visible learning: A synthesis of over 800 meta-analyses relating to achievement. Hoboken, NJ: Taylor \& Francis.

[16] Hoque, K.E., Kenayathulla, H.B.Bt., Subramaniam, M.V., \& Islam, R. (2020). Relationships Between Supervision and Teachers' Performance and Attitude in Secondary Schools in Malaysia. SAGE Open, 10(2): 1-11.

[17] Jami, A., M. A., Ali, U., Baloch, J.-u.-R., \& Ayaz, M. (2011). Effects of In-Service Training in Meliorating Teachers performance In Secondary Schools. International Journal of Academic Research, 1-6.

[18] Kazu, İ. Y., \& Erten, P. (2016). Teachers' lifelong learning competencies. Elementary Education Online, 15(3), 838854.

[19] Kennedy, A. (2014). Understanding continuing professional development: The need for theory to impact on policy and practice. Professional Development in Education, 40(5): 688-697.

[20] Khan, S., \& Abdullah, N. N. (2019). The impact of staff training and development on teachers' productivity. Economics, Management and Sustainability, 4(1), 37-45.

[21] Khun-inkeeree, H., Dali, P. D., Daud, Y., Fauzee, M. S. O., \& Khalid, R. (2019). Effects of teaching and learning supervision on teachers attitudes to supervision at secondary school in Kubang Pasu District, Kedah. International Journal of Instruction, 12(1), 1335-1350.

[22] Kiel, E., Lerche, T., Kollmannsberger, M., Oubaid, V., \& Weiss, S. (2016). The Pedagogic Signature of the Teaching Profession. Journal of Education and Learning, 5(4): 201-220.

[23] König, J., Blömeke, S., Paine, L., Schmidt, W.H., \& Hsieh, F.-J. (2011). General pedagogical knowledge of future middle school teachers: On the complex ecology of teacher education in the United States, Germany, and Taiwan. Journal of Teacher Education, 62(2): 188 -201.

[24] Leithwood, K., Leonard, L., \& Sharratt, L. (2015). Conditions fostering organizational learning in schools.
Educational Administration Quarterly, 34(2): 243-276.

[25] Lotunanti, A., Idrus, M, S., Afnan, E., \& Setiawan, M. (2014). The Effect of Competence on Commitment, Performance and Satisfaction with Reward as a Moderating Variable (A Study on Designing Work plans in Kendari City Government, Southeast Sulawesi). International Journal of Business and Management Invention. 3(2). 18-25

[26] Lyles, R. (2015). Teachers and Professionalism. The Clearing House: A Journal of Educational Strategies, Issues and Ideas, 30(9), 548-550.

[27] Marlow, E. (2016). The Principal as Supervisor in the School Setting. Academic Journal: Education, 136(3).

[28] Mawoli, M. A., \& Babandako, A.Y. 2011. An Evaluation of Staff Motivation, Dissatisfaction and Job Performance in an Academic Setting. Australian Journal of Business and Management Research, 1(9)

[29] Mueller, C, M., (2012). The Impact of Teacher Certification Programs on Teacher Efficacy, Job Satisfaction, and Teacher Performance: A Comparison of Traditional and Alternative Certification. Western Kentucky University.

[30] Nadeem, M., Rana, M.S., Lone, A.H., Maqbool, S., Naz, K., Ali, A. (2011). Teacher's Competencies and Factors Affecting the Performance of Female Teachers in Bahawalpur (Southern Punjab) Pakistan. International Journal of Business and Social Science, 2(19): 217-222.

[31] Nurhattati, Matin, Buchdadi, A.D, \& Yusuf, C.F. (2020). Teacher Certification in Indonesia: An Education Policy Analysis. Universal Journal of Educational Research, 8(5), $1719-1730$

[32] Nurhayati, T., Masnun, M., Udin, T., \& Arifuddin, A. (2019). Implementation of principal supervision as an effort to fulfill teacher administration at Islamic elementary school. Universal Journal of Educational Research, 7(8), 1826-1831.

[33] Osakwe, R. (2010). The relationship between principals' supervisory strategies and teachers' instructional performance in Delta North Senatorial District, Nigeria. Pakistan Journal of Social Sciences, 7(6), 437-440.

[34] Parker, L. (2018). Teacher Competencies or Certification Competencies. Behavioral Disorders, 5(3), 163-168.

[35] Poro, S.G., Yiga, A.P., Enon, J.C., Mwosi, F., Eton, M. (2018). Teacher competence and performance in primary schools in Nwoya District, Northern Uganda. International Journal of Advanced Educational Research, 4(1): 3-8.

[36] Rockoff, J. E. (2004). The impact of individual teachers on student achievement: Evidence from panel data. American Economic Review, 94(2), 247e252.

[37] Salim, A., Setyosari, P., Kamdi, W., \& Dasna, I. W. (2019). Improving Competency Management of Public Health Center in Indonesia Using the Problem Based Learning Model. Journal for the Education of Gifted Young Scientists, 7(3), 731-746.

[38] Shukla, S. (2014). Teaching Competency, Professional Commitment and Job Satisfaction-A Study of Primary School Teachers. IOSR Journal of Research \& Method in Education, 4(3): 44-64.

[39] Stark, D., McGhee, M. W., \& Jimerson, J. B. (2017). 
Reclaiming instructional supervision: Using solution-focused strategies to promote teacher development. Journal of Research on Leadership Education. 12(3), 215238.

[40] Stark, D., McGhee, M. W., \& Jimerson, J. B. (2017). Reclaiming instructional supervision: Using solution-focused strategies to promote teacher development. Journal of Research on Leadership Education. 12(3), 215238.

[41] Steele, D., \& Zhang, R. (2016). Enhancement of Teacher Training: Key to Improvement of English Education in Japan. Procedia- Social and Behavioral Science, 217(2016): 16-25.

[42] Sung, Yao-Ting., Chang, Kuo-En., \& Liu, Tzu-Chien. (2016). The effects of integrating mobile devices with teaching and learning on students' learning performance: A meta-analysis and research synthesis. Computers \& Education, 94(1): 252-275.

[43] Suseela, M., (2015). Teacher learning in Malaysia: Problems and possibilities of reform. Kuala Lumpur: University of Malaya.
[44] Timperley, H., \& Alton-Lee, A. (2008). Reframing teacher professional learning: An alternative policy approach to strengthening valued outcomes for diverse learners. Review of Research in Education, 32, 328e369.

[45] Too, C., Kimutai, C. K., \& Kosgei, Z. (2012). The impact of head teachers' supervision of teachers on students' academic performance. Journal of Emerging Trends in Educational Research and Policy Studies, 3(3), 299-306.

[46] Yafie, E., Haqqi, Y. A., Kustiawan, U., Astuti, W., Boedi, D., \& Ilhami, B. S. (2020). The Effect of Teacher Competency Training on High Order Thinking-Based Learning. JECCE (Journal of Early Childhood Care and Education), 2(2), 87-93

[47] Yafie, E., Samah, N. A., Mohamed, H. \& Haqqi, Y. A. (2020) Collaborative Mobile Seamless Learning (CMSL) based on Android Apps to Improving Critical Thinking in Higher Education in the Post-Covid-19 Era. Jour of Adv Research in Dynamical \& Control Systems, 12 (07), 428-441

[48] Yousaf, S.U., Usman, B., \& Islam, T. (2018). Effects of Supervision Practices of Principals on Work Performance and Growth of Primary School Teachers. Bulletin of Education and Research, 40(1): 285-298. 